\title{
Distinctive Effects of Red Wine and Diet on Haemostatic Cardiovascular Risk Factors
}

\author{
DIEGO MEZZANO
}

Department of Hematology-Oncology, Faculty of Medicine, Catholic University of Chile, Santiago, Chile

\begin{abstract}
The aim of this study was to compare the effects of Mediterranean-type diet (MD), high-fat diet (HFD), and red wine supplementation on plasma concentration of emergent haemostatic cardiovascular risk factors (HCVRF) and on variables of primary haemostasis (bleeding time, plasma von Willebrand factor and platelet aggregation/secretion). In a controlled prospective intervention study, two groups (21 healthy males each) received either MD or HFD during 90 days. Between days 30-60, both diets were supplemented with $240 \mathrm{ml} /$ day of red wine. After adjusting by baseline values, MD was associated with: lower plasma fibrinogen ( $p$ $=0.03)$, factor VIIc $(\mathrm{p}=0.034)$ and factor VIIIc $(\mathrm{p}=0.0057)$; higher levels of protein $\mathrm{S}(\mathrm{p}=0.013)$; longer bleeding time $(\mathrm{p}=0.017)$; and marginal increases in platelet serotonin aggregation and secretion after stimulation with epinephrine. Red wine supplementation, in both diets, resulted in decreased plasma fibrinogen $(\mathrm{p}=0.001)$ and factor VIIc $(\mathrm{p}=0.05)$, and in increased t-PA $(\mathrm{p}=0.01)$ and PAI-1 $(\mathrm{p}=0.0003)$. The effects of wine on antithrombin III $(\mathrm{p}=0.01)$ were divergent: there was a decrease in the HFD group but it increased slightly in the MD group. No effects of diet or wine were detected in plasma protein C, C-reactive protein or von Willebrand factor. BT did not change significantly with wine supplementation. Wine intake resulted in a significant increase in ex vivo platelet aggregation and secretion after stimulation with collagen ( 1 and $2 \mu \mathrm{g} / \mathrm{ml}, \mathrm{p} \leq 0.01)$. MD and moderate consumption of red wine have complementary, mostly beneficial effects on haemostatic CV risk factors. The longer BT in individuals on MD, obtained independently of red wine, denotes less interaction of platelets with the vascular wall, which could be beneficial from the point of view of CV risk.
\end{abstract}

Key words: Bleeding time, cardiovascular risk factors, diet, haemostasis, platelet function, wine.

Abbreviations: BT: bleeding time; CV: cardiovascular; HCVRF: haemostatic cardiovascular risk factors; HFD: high-fat diet; MD: Mediterranean-type diet; NO: nitric oxide; PAI-1: plasminogen activator inhibitor; PGI2: prostacyclin; t-PA: tissue plasminogen activator; vWF:Ag: von Willebrand factor.

\section{INTRODUCTION}

Intervention and epidemiological studies show that certain dietary habits and light-tomoderate alcohol consumption provide cardiovascular $(\mathrm{CV})$ protection. These effects were recently summarized indicating that foods of animal origin were directly correlated to coronary heart disease mortality, whereas an inverse correlation was found for vegetable-food groups, fish and alcohol (Menotti et al., 1999). Populations consuming a diet rich in vegetables, olive oil, fish and wine (Mediterranean diet, MD) had the lowest mortality among the seven countries included in that study. The benefits of this diet can apparently be transferred to populations of other ethnic origins (KourisBlazos et al., 1999) and have also been reproduced in secondary prevention trials (de Lorgeril et al., 1999).

Alcoholic beverages, mostly wine, are a constitutive component of the MD. Wine itself appears to add an independent CV benefit to this diet (Grønbæk et al., 2000). However, despite reports indicating that lightto-moderate alcohol consumption reduces both CV mortality (Thun et al., 1997) and the risk of stroke (Berger et al., 1999), wine drinking has also been related to the intake of 
healthier diets (Tjonneland et al., 1999) and other advantageous lifestyle characteristics (Wannamethee and Shaper, 1999) to which $\mathrm{CV}$ benefits are attributed. Thus, the health benefits of phenolic acids and polyphenols contained in red wine may be indiscernible in populations that ingest large amounts of fruits and vegetables, whereas these benefits could be distinctly apparent in populations with relatively low intakes of these kinds of foods (de Lorgeril et al., 1999). In this regard, the proposal that wine is a major determinant of the benefits derived from MD and the French paradox (Renaud and de Lorgeril, 1992) still needs to be demonstrated.

Lower rates of $\mathrm{CV}$ disease and mortality in Southern European countries could be only partially explained by differences in fat intake or in blood lipid profiles (Langer et al., 1992). Accordingly, additional mechanisms, like changes in plasma levels of haemostatic factors, should contribute to this protection. Some of these factors have emerged as predictors for coronary heart disease (Ridker, 1997; Medina et al., 2003); furthermore, several reports indicate that these are modifiable by diet and alcohol (including wine). In fact, MD on the whole (Bijnen et al., 1996) or distinctive components of this diet, such as lower saturated fat consumption, as well as higher intakes of monounsaturated fatty acids, fruits and vegetables (Weststrate et al., 1998; Roche et al., 1998; Temme et al., 1999; Mezzano et al., 1999), appear related to a more favorable profile of HCVRF. The same holds true for alcohol or wine, as summarized in a meta-analysis which revealed that $\mathrm{CV}$ benefits of alcohol intake are mostly mediated through changes in blood lipids and HCVRF, mainly fibrinogen (Rimm et al., 1999).

Platelet-vascular wall interactions (primary haemostasis) play a key role in arterial thrombotic events. This explains the increasing use of platelet inhibitors to prevent or treat these conditions. In this context, some of the beneficial effects of MD and wine consumption could be mediated by a reduction in platelet reactivity. Several studies report that diets enriched with fish, $\alpha$-linolenic acid and spices, abundant in MD, include substances that reduce or could reduce platelet function (Vognild et al., 1998; Allman et al., 1995;
Janssen et al., 1998; Ackerman et al., 2001; Srivastava et al., 1995). Similarly, other reports indicate that the intake of moderate amounts of ethanol or non-alcoholic components of wine for two or more weeks, are associated with a decrease in ex vivo platelet function (Pikkar et al., 1987; Pellegrini et al., 1996; Pace-Asciak et al., 1996; Freedman et al., 2001).

In this symposium, we summarize the results of an intervention study performed in our unit, which have been recently published (Mezzano et al., 2001; Mezzano et al., 2003). The objectives of the studies were two-fold: First, to compare the effects of two alcohol-free diets, a Mediterraneantype and a high-fat Western-type diet (HFD) on plasma concentration of emergent haemostatic cardiovascular risk factors (HCVRF) and on variables of primary haemostasis (bleeding time, plasma von Willebrand factor and platelet aggregation/ secretion). Second, we tested if red wine supplementation of both diets modifies these variables, independent of the type of diet.

\section{Study design}

This was a controlled prospective intervention study in which two groups, each of 21 healthy male university students $(22 \pm 3.4$ years), received either MD or HFD during 90 days. Between days 30-60, both diets were supplemented with $240 \mathrm{ml} /$ day of red wine. Baseline (T0) and T30, T60 and T90-day samples were drawn. Bleeding time (BT) was measured before and after wine supplementation (day 30 and day 60 respectively). No drop out from the study was observed. A diagram showing the design of the intervention study is shown in Figure 1.

\begin{tabular}{|l|l|c|c|}
\hline GRUPO 1 & MEDITERRANEAN DIET & $\begin{array}{c}\text { MEDITERRANEAN DIET } \\
+ \\
\text { RED WINE }\end{array}$ & MEDITERRANEAN DIET \\
\cline { 2 - 4 } & 30 Days & 30 Days & 30 Days \\
\cline { 2 - 4 } & GRUPO 2 \\
\cline { 2 - 4 } & $\begin{array}{c}\text { HIGHFAT DIET } \\
+ \\
\text { HED WINE }\end{array}$ & HIGHFAT DIET \\
\hline
\end{tabular}

Figure 1. Diagram of the diet and wine intervention design. 
We measured procoagulant HCVRF (plasma fibrinogen, factors VIIc and VIIIc), anticoagulant proteins (antithrombin III, proteins $\mathrm{C}$ and $\mathrm{S}$ ), profibrinolytic factor (tissue plasminogen activator, t-PA), antifibrinolytic factor (plasminogen activator inhibitor, PAI-1) and variables of platelet-vessel wall interaction: BT (an overall in vivo test assessing this interaction), plasma von Willebrand factor (vWF:Ag), which initiates the platelet adhesion to the vascular wall and platelet aggregation and secretion capacity after stimulation with various agonists.

\section{RESULTS}

To test the compliance with diets, we measured several variables, which distinguish the intake of MD and HFD after 30 days of either one or the other diet. As expected, individuals on MD had significantly higher levels of plasma $\beta$ carotene $(0.49 \pm 0.19$ vs. $0.23 \pm 0.14 \mu \mathrm{mol} /$ $\mathrm{L} ; \mathrm{p}<0.0001)$, ascorbate $(55.9 \pm 11.2$ vs. $29.7 \pm 8.9 \mu \mathrm{mol} / \mathrm{L} ; \mathrm{p}<0.0001)$, folate $(14.2$ \pm 4.3 vs. $10.5 \pm 2.6 \mathrm{nmol} / \mathrm{L} ; \mathrm{p}=0.0019)$ and eicosapentaenoic acid in the plasma lipid fraction $(1.5 \% \pm 0.7$ vs. $0.85 \% \pm 0.3$; $\mathrm{p}=0.001)$, than those on HFD. Interestingly, dietary and wine interventions did not result in significant changes, at any time point, in total plasma cholesterol (Fig 2), HDL and LDL in either study group, confirming the notion that diet effects on $\mathrm{CV}$ risk could be independent of changes in plasma lipid profile.

No significant differences were observed in plasma concentration of HCVRF at baseline (T0) between groups on MD and HFD. Given that inflammatory stimuli induce increase in some coagulation proteins, C-reactive protein was measured at all times in all volunteers as a control for inflammatory changes within individuals and within groups. Neither significant baseline differences, nor changes induced by diet or wine in this inflammatory marker were observed (results not shown).

The effects of diet alone were tested comparing values of each variable for MD and HFD at T0 and T30, a period without wine supplementation (Fig 3). Volunteers on HFD at T30 had $22 \%$ increase in procoagulants fibrinogen, $9 \%$ increase in factor

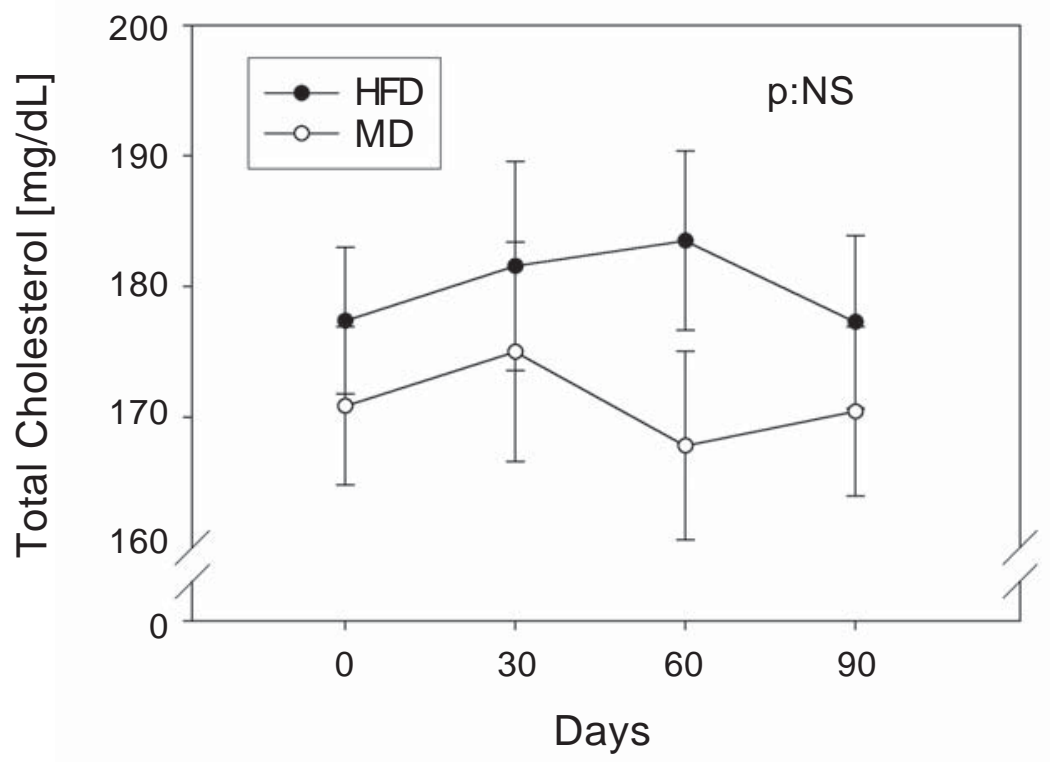

Figure 2. Comparative effect of Mediterranean diet (MD) and high-fat diet (HFD), and effect of red wine on total serum cholesterol. Volunteers received red wine from day 30 through 60 . The observed differences between diets and after wine intake were not significantly different. 

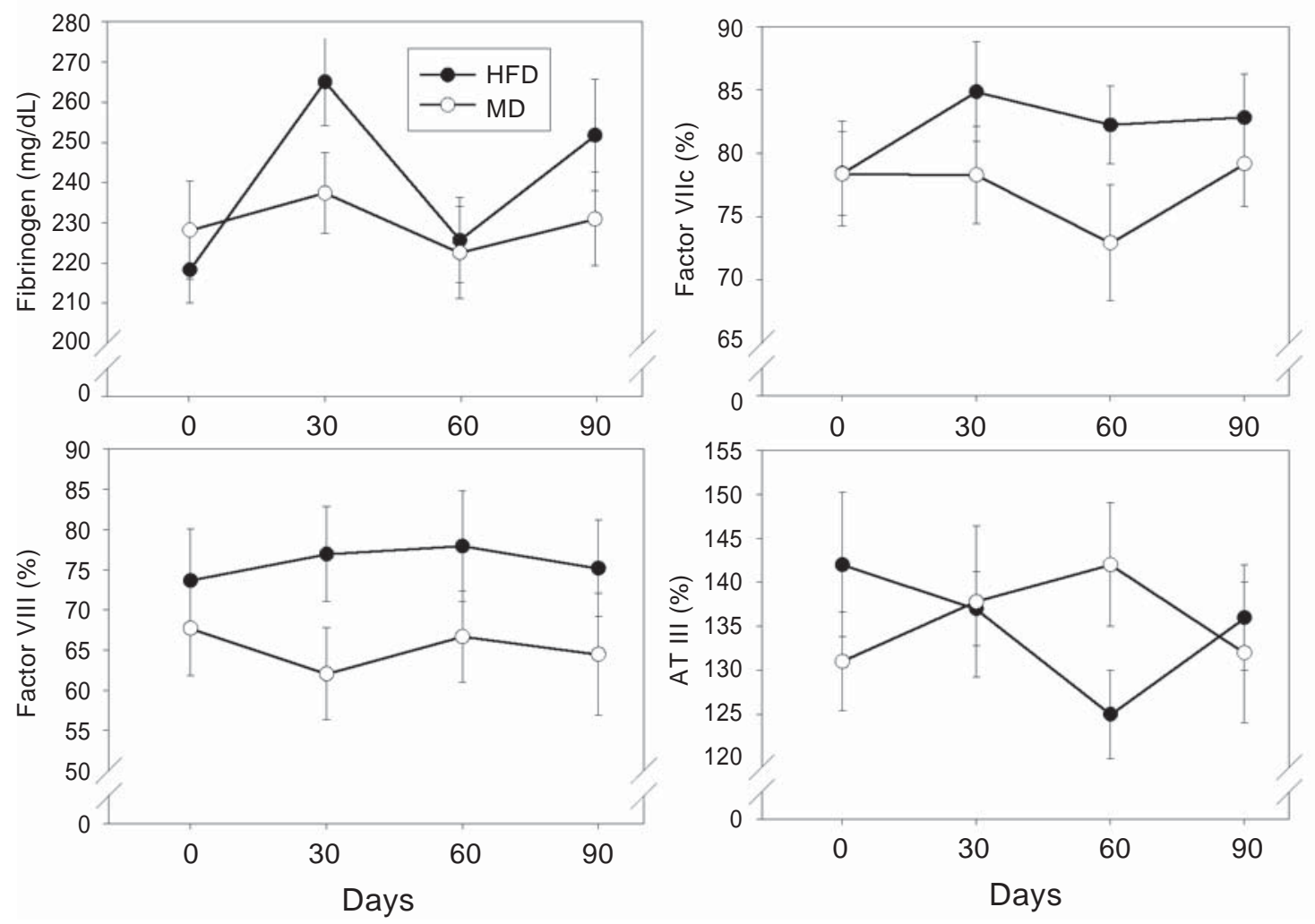

Figure 3. Comparative effect of Mediterranean diet (MD) and high-fat diet (HFD), and effect of red wine on plasma fibrinogen, factor VIIc, factor VIIIc and antithrombin III. Volunteers received red wine from day 30 through 60 . At T30 there was a diet-related difference in fibrinogen $(\mathrm{p}=0.03)$, factor VIIc $(\mathrm{p}=0.034)$ and factor VIIIc $(\mathrm{p}=0.0057)$ levels, with lower values in individuals on MD. For the natural anticoagulant antithrombin III, the inverse effect observed with each diet abolished the difference at $\mathrm{T} 0$. Wine intake was associated with decreases in plasma fibrinogen $(\mathrm{p}=$ $0.0005)$ and in factor VIIc $(\mathrm{p}=0.05)$. The mean change in AT III Ag after wine consumption differed significantly in volunteers on HFD when compared with those on MD ( $p=0.01)$.

VIIc, and $4 \%$ in factor VIIIc, and decreases in natural anticoagulants antithrombin III (3 $\%)$, protein $\mathrm{C}(11 \%)$ and protein $\mathrm{S}(6 \%)$ and of $20 \%$ in plasminogen activator inhibitor-1 (PAI-1) (data for antithrombin III is also shown in Fig 3). At the same time, individuals on MD had marginal increases in fibrinogen (4\%), antithrombin III (5\%), protein $\mathrm{C}(3 \%)$, protein $\mathrm{S}(2.7 \%)$, and decreases in factor VIIIc $(9 \%)$, and plasminogen activator inhibitor-1 (PAI-1, $21 \%$, Fig 4). After adjusting by baseline values, MD was associated with lower plasma procoagulants fibrinogen $(\mathrm{p}=0.03)$, factor VIIc $(p=0.034)$ and factor VIIIc $(\mathrm{p}=0.0057)$ and with higher levels of the anticoagulant protein $\mathrm{S}(\mathrm{p}=0.013)$. Taken together, all these changes can be interpreted as indicating a $\mathrm{CV}$ protection of MD against thrombin generation and fibrin clot deposition in the circulation.

The effect of red wine supplementation was tested comparing values obtained after 30 days with wine (T60) in both diets, with values at $\mathrm{T} 30+\mathrm{T} 90 / 2$. Furthermore, to control for a longer than expected wine effect, comparisons at T60 and T30 were performed. As shown in the same Figures, wine intake resulted in a diet-independent decrease in plasma fibrinogen $(\mathrm{p}=0.001)$ 
and factor VIIc $(\mathrm{p}=0.05)$, and in an increase in tissue plasminogen activator antigen ( $\mathrm{t}-$ $\mathrm{PA})(\mathrm{p}=0.01)$ and plasminogen activator inhibitor-1 antigen (PAI-1) $(\mathrm{p}=0.0003)$. Wine consumption was also associated with significantly $(\mathrm{p}=0.01)$ divergent effects on antithrombin III: it decreased by $10 \%$ in individuals on HFD but increased slightly in those on MD. These findings show that red wine intake has an overall potentiating effect of MD, by decreasing the procoagulant potential of plasma and increasing its anticoagulant properties. In this regard, the wine-induced increase in plasminogen activator inhibitor-1 antigen (PAI-1) is paradoxical, since its net effect would be a decrease in the capacity of plasma to lyse clots.

With regard to variables related to platelet-vessel wall interaction, individuals on $\mathrm{MD}$ had longer BT than those on HFD $(7.6 \pm 2.8$ vs. $5.8 \pm 1.7 \mathrm{~min} ; \mathrm{p}=0.017)$ measured at T30 (Fig 5). BT did not change significantly after 1 month of wine supplementation $(7.1 \pm 2.0$ vs. $5.5 \pm 2.0 \mathrm{~min}$, respectively). BT is an in vivo test which is altered in conditions of abnormal interactions of platelets with the vessel wall. Plasma concentration of von Willebrand factor was not significantly different between diet groups at baseline and did not change significantly at 30,60 or 90 days. Von Willebrand factor is a three-compartment (intraplatelet, circulating and subendothelium matrix) glycoprotein which mediates the interaction of platelets with the vascular wall, and whose increased concentration has been directly related with $\mathrm{CV}$ risk. MD intake was associated with an increase in platelet serotonin secretion $(p=0.02)$ after stimulation with epinephrine. Wine intake resulted in a marginal decrease in platelet ${ }^{14} \mathrm{C}-5-\mathrm{HT}$ (serotonin) secretion with $4 \mu \mathrm{M}$ ADP $(p=0.07)$, whereas both platelet aggregation and secretion were consistently increased when using collagen as agonist ( $p$ $\leq 0.01)$. These results stand against the commonly accepted notion that red wine decreases the $\mathrm{CV}$ risk by inhibiting platelet function, appealing for additional explanations for the French paradox (Renaud S and de Lorgeril M, 1992).

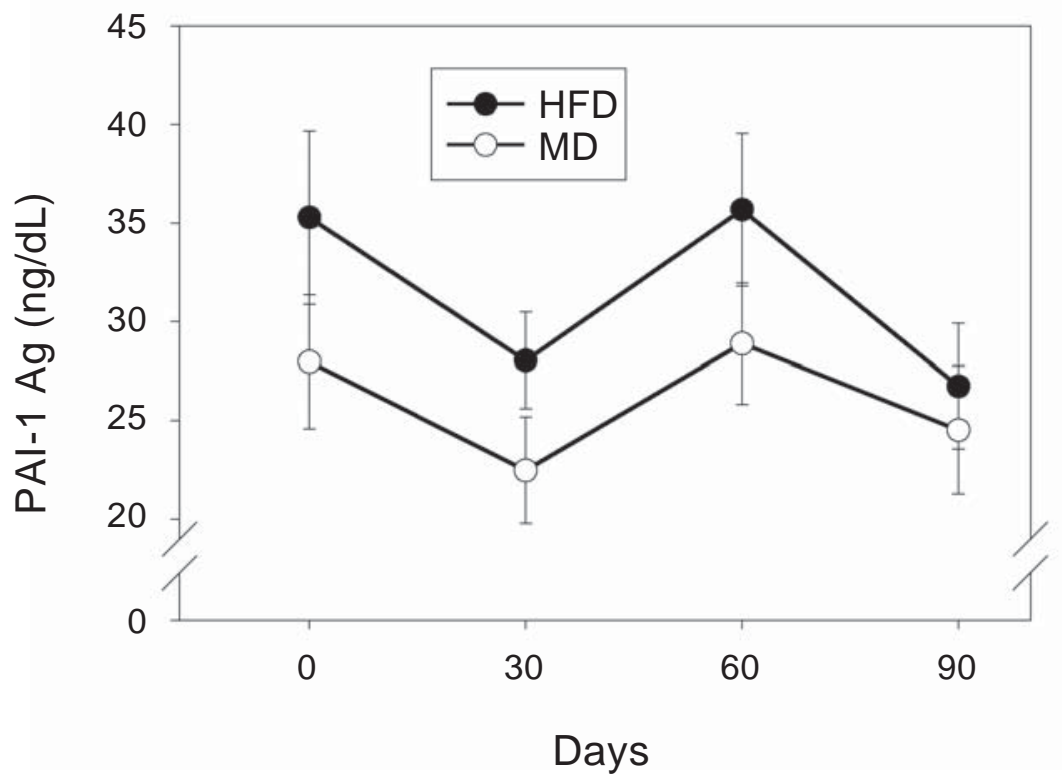

Figure 4. Comparative effect of Mediterranean diet (MD) and high-fat diet (HFD), and effect of red wine on plasma plasminogen activator inhibitor-1 antigen (PAI-1 Ag). Volunteers received red wine from day 30 through 60. Wine intake was associated with increase in plasma PAI-1 Ag (p = 0.0001). 


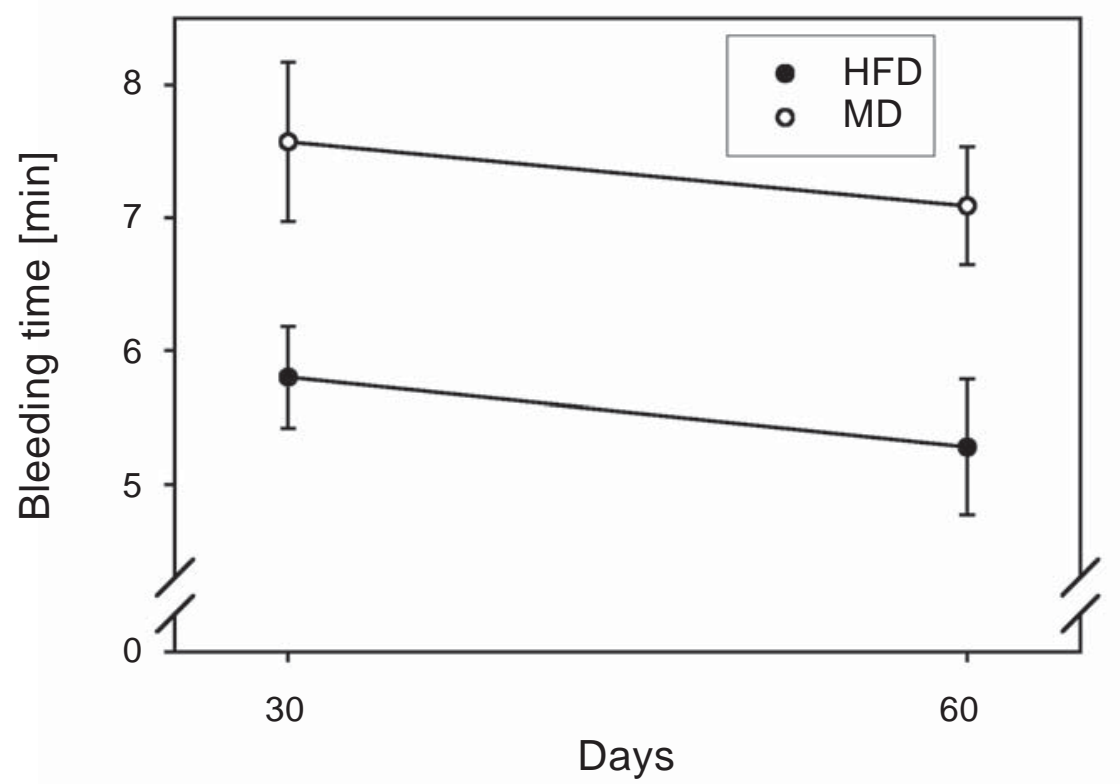

Figure 5. Comparative effect of Mediterranean diet (MD) and high-fat diet (HFD) and the effect of red wine on bleeding time. Values were recorded after 1 month on each diet (day 30) and after 1 month of supplementation of both diets with red wine (day 60). "p" value reflects the difference in BT between diets. Red wine intake was not associated with significant changes in bleeding time. Bars represent mean $\pm \mathrm{SD}$.

\section{CONCLUSIONS}

MD and moderate consumption of red wine have complementary, mostly beneficial effects on HCVRF. Our studies confirmed the overall health advantage of a MD (less total and saturated fats and red meat, but richer in monounsaturated fatty acids, white meat, fish, fruits and vegetables). It also revealed that the addition of a moderate amount of red wine further improves the haemostatic profile of this type of diet, as well as that of individuals with higher fat diets. The net effect of combining diet and red wine is a decrease in the procoagulant potential of plasma. However, a note of caution must be added, regarding a possible antifibrinolytic effect of wine, when it supplements the MD.

With respect to primary haemostasis, MD, independent of wine, was found associated with a longer BT. This finding denotes less interaction of platelets with the vascular wall, which could be beneficial from the point of view of CV risk. This effect is not explained by changes in the measured haemostatic determinants of BT (plasma von Willebrand Factor, ex vivo platelet function), and might be attributed to other yet unknown vascular factors.

It is unlikely that abundance of fish or $\omega-3$ fatty acids in the diet could explain the observed effects (Dyerberg and Bang, 1979; Goodnight et al., 1981), because fish intake in our MD group was lower than that used in previous specific intervention studies, and it did not result in significant changes in platelet aggregation/secretion. Nitric oxide (NO) and prostacyclin $\left(\mathrm{PGI}_{2}\right)$ produced by endothelial cells reduce platelet-vessel wall interactions and both induce prolongation of BT (Simon et al., 1995; Ubatuba et al., 1979; Gerrard et al., 1992). In this context, it is possible that the modulation of $\mathrm{NO}$ on platelet-endothelium interactions could account for the longer BT presently observed for individuals on MD.

However, a highly significant increase in the aggregation and secretion of platelets exposed to low and high collagen concentrations was observed. This finding 
contests the widespread notion, summarized in recent reviews, that red wine inhibits platelet function (Wollin and Jones, 2001; Booyse and Parks, 2001). In fact, the undisputed $\mathrm{CV}$ benefits of moderate red wine consumption parallels the wide consensus that wine effects are, at least in part, induced by inhibiting platelet reactivity (Ruf, 2004). This notion is weakened by the fact that published studies assessing the effect of wine on platelets are highly heterogeneous and that the inhibition observed with a single stimulus is often not reproduced with other agonists. Moreover, a distinct increase in ex vivo platelet function has been observed with some agonists in association with wine intake, and an additional increase in platelet reactivity, referred to as the rebound effect, has been noted after alcohol withdrawal (Renaud and Ruf, 1996). In this regard, our finding of increased platelet aggregation/ secretion with collagen closely resembles a rebound effect, given that it arises several hours after the last drink, with no alcohol remaining in the blood. This situation best reflects the physiological status of a moderate wine drinker.

The potential antithrombotic advantage of consuming a Mediterranean-type diet associated with a moderate amount of red wine has not a straightforward biological explanation. Even though a balanced ratio of $\omega-6 / \omega-3$ essential fatty acids and abundance of antioxidant compounds may have a mild anti-inflammatory effect (de Lorgeril and Salen, 2000), the lack of significant differences in plasma levels of C-reactive protein between both diets does not support this interpretation. The possibility that a decreased oxidative injury derived from $M D$ and red wine consumption (Visioli, 2000) modulates the coagulation system deserves a systematic evaluation.

In our studies, we tested the effect of red wine because it constitutes the major alcoholic beverage consumed with MD. As previously discussed, some of the effects observed in our study have also been attributed to ethanol contained in other alcoholic beverages. It remains to be established the relative contributions of alcohol and other constituents of red wine, such as polyphenols, in the improved CV risk factor profile associated to moderate red wine intake.

\section{REFERENCES}

ACKERMAN RT, MULROW CD, RAMÍREZ G, GARDNER CD, MORBIDONI L, LAWRENCE VA (2001) Garlic shows promise for improving some CV risk factors. Arch Intern Med 161: 813-824

ALLMAN MA, PENA MM, PANG D (1995) Supplementation with flaxseed oil versus sunflower seed oil in healthy young men consuming a low fat diet: effects on platelet composition and function. Eur J Clin Nutr 49: 169-178

BERGER K, AJANI UA, KASE CS, GAZIANNO JM, BURING JE, GLYNN RJ, HENNEKENS CH (1999) Light- to-moderate alcohol consumption and the risk of stroke among U.S. male physicians. N Engl J Med 341: $1557-1564$

BIJNEN FCH, FESKENS EJM, GIAMPAOLI S, MENOTTI A, FIDANZA F, HORNSTRA G, CASPERSEN CJ, MOSTERD WL, KROMHOUT D (1996) Haemostatic parameters and lifestyle factors in elderly men in Italy and The Netherlands.Thromb Haemost 76: 411-416

BOOYSE FM, PARKS DA (2001) Moderate wine and alcohol consumption: beneficial effects on cardiovascular disease. Thromb Haemost 86: 517-528

DE LORGERIL M, SALEN P (1999) Wine ethanol, platelets, and mediterranean diet. Lancet 353: 1067

DE LORGERIL M, SALEN P, MARTIN JL, MONJAUD I, DELAYE J, MAMELLE N (1999) Mediterranean diet, traditional risk factors, and the rate of cardiovascular complications after myocardial infarction: final report of the Lyon Diet Heart Study. Circulation 99: 779-785

DE LORGERIL M, SALEN P (2000) Modified Cretan Mediterranean diet in the prevention of coronary heart disease and cancer. In Mediterranean Diets, ed. AP Simopoulos and F Visioli, pp. 1-23 Basel, Karger

DYERBERG J, BANG HO (1979) Haemostatic function and platelet polyunsaturated fatty acids in Eskimos. Lancet 2: 433-435

FREEDMAN JE, PARKER C III, LI L, PERLMAN JA, FREI B, IVANOV V, DEAK LR, IAFRATI MD, FOLTS JD (2001) Select flavonoids and whole juice from purple grapes inhibit platelet function and enhance nitric oxide release. Circulation 103: 27922798

GERRARD JM, DUTA E, NOSEK-CENKOWSKA B, SINGHROY S, CHEANG M, KOBRINSKY NL (1992) A role for prostacyclin in bruising symptomatology. Pediatrics 90: 33-36

GOODNIGHT SH Jr, HARRIS WS, CONNOR WE (1981) The effects of dietary omega 3 fatty acids on platelet composition and function in man: a prospective, controlled study. Blood 58: 880-885

GRONBAEK M, BECKER U, HOHANSEN D, GOTTSCHAU A, SCHNOHR P, HEIN HO, JENSEN G, SORENSEN TIA (2000) Type of alcohol consumed and mortality from all causes, coronary heart disease, and cancer. Ann Int Med 133: 411-419

JANSSEN K, MENSINK RP, COX FJ, HARRYVAN JL, HOVENIER R, HOLLMAN PC, KATAN MB (1998) Effects of the flavonoids quercetin and apigenin on hemostasis in healthy volunteers: results from an in 
vitro and a dietary supplement study. Am J Clin. Nutr 67: $255-262$

KOURIS-BLAZOS A, GNARDELLIS C, WAHLQUIST ML, TRICHOPOULOS D, LUKITO W, TRICHOPOULOU A (1999) Are the advantages of the Mediterranean diet transferable to other populations? A cohort study in Melbourne, Australia. Br J Nutr 82: 57-61

LANGER RD, CRIQUI MH, REED DM (1992) Lipoproteins and blood pressure as biological pathways for effect of moderate alcohol consumption on coronary heart disease. Circulation 85: 910-915

MEDINA RA, ARANDA E, VERDUGO C, KATO S, OWEN GI. (2003) The action of ovarian hormones in cardiovascular disease. Biol Res 36: 325-341

MENOTTI A, KROMHOUT D, BLACKBURN H, FIDANZA F, BUZINA R, NISSINEN A (1999) Food intake patterns and 25-year mortality from coronary heart disease: cross-cultural correlations in the Seven Countries Study. The Seven Countries Study Research Group. Eur J Epidemiol 15: 507-515

MEZZANO D, MUÑOZ X, MARTÍNEZ C, CUEVAS A, PANES O, ARANDA E, GUASCH V, STROBEL P, MUÑOZ B, RODRÍGUEZ S, PEREIRA J, LEIGHTON F (1999) Vegetarians and cardiovascular risk factors: haemostasis, inflammatory markers and plasma homocysteine. Thromb Haemostas 81: 913-917

MEZZANO D, LEIGHTON F, MARTÍNEZ C, MARSHALL G, CUEVAS A, CASTILLO O, PANES O, MUÑOZ B, PÉREZ DD, MIZON C, ROZOWSKI J, SAN MARTÍN A, PEREIRA J (2001) Complementary effects of Mediterranean diet and moderate red wine intake on haemostatic cardiovascular risk factors. Eur J Clin Nutr 55: 444-451

MEZZANO D, LEIGHTON F, STROBEL P, MARTÍNEZ C, MARSHALl $G$, CUEVAS A, CASTILlO O, PANES O, MUÑOZ B, ROZOWSKI J, PEREIRA J (2003) Mediterranean diet, but not red wine, is associated with beneficial changes on primary haemostasis. Eur J Clin Nutr 57: 439-446

PACE-ASCIAK CR, ROUNOVA O, HAHN SE, DIAMANDIS EP, GOLDBERG DM (1996) Wines and grape juices as modulators of platelet aggregation in healthy human subjects. Clin Chim Acta 246: 163-182

PELLEGRINI N, PARETI FI, STABILE F, BRUSAMOLINO A, SIMONETTI P (1996) Effect of moderate consumption of red wine on platelet aggregation and haemostatic variables in healthy volunteers. Eur J Clin Nutr 50: 209-213

PIKKAR NA, WEDEL M, VAN DER BEEK EJ, VAN DIKKUM W, KEMPEN HJ, KLUFT C, OCKHUIZEN T, HERMUS RJ (1987) Effects of moderate alcohol consumption on platelet aggregation, fibrinolysis, and blood lipids. Metabolism 36: 538-543

RENAUD S, DE LORGERIL M (1992) Wine, alcohol, platelets, and the French paradox for coronary heart disease. Lancet 339: 1523-1526

RENAUD SC, RUF J-C (1996) Effects of alcohol on platelet functions. Clin Chim Acta 246: 77-89

RIDKER PM (1997) Fibrinolytic and inflammatory markers for arterial occlusion: the evolving epidemiology of thrombosis and hemostasis. Thromb Haemostas 78: 53-59
RIMM EB, WILLIAMS P, FOSHER K, CRIQUI M, STAMPFER MJ (1999) Moderate alcohol intake and lower risk of coronary heart disease: meta-analysis of effects on lipids and haemostatic factors. BMJ. 319: $1523-1528$

ROCHE HM, ZAMPELAS A, KNAPPER JM, WEBB D, BROOKS C, JACKSON KG, WRIGHT JW, GOULD BJ, KAFATOS A, GIBNEY MJ, WILLIAMS CM (1998) Effect of long-term olive oil dietary intervention on postprandial triacylglycerol and factor VII metabolism. Am J Clin Nutr 68: 552-560

RUF JC (2004) Alcohol, Wine and Platelet Function. Biol Res 37: 209-215

SIMON DI, STAMLER JS, LOH E, LOSCALZO J, FRANCIS SA, CREAGER MA (1995) Effects of nitric oxide synthase inhibition on bleeding time in humans. J Cardiovasc Pharmacol 26: 339-342

SRIVASTAVA KC, BORDIA A, BERMA SK (1995) Curcumin, a major component of food spice turmeric (Curcuma longa) inhibits aggregation and alters eicosanoid metabolism in human blood platelets. Prostaglandins Leukot Essent Fatty Acids 52: $223-227$

TEMME EH, MENSINK RP, HORNSTRA G (1999) Effects of diets enriched in lauric, palmitic or oleic acids on blood coagulation and fibrinolysis. Thromb Haemost 81: 259-263

THUN MJ, PETO R, LÓPEZ AD, MONACO JH, HENLEY SJ, HEATH CW JR, DOLL R (1997) Alcohol consumption and mortality among middle-aged and elderly U.S. adults. N Engl. Med 337: 1705-1714

TJONNELAND A, GRONBAEK M, STRIPP C, OVERVAD K (1999) Wine intake and diet in a random sample of 48,763 Danish men and women. Am J Clin Nutr 69: 49-54

UBATUBA FB, MONCADA S, VANE JR (1979) The effect of prostacyclin (PGT2) on platelet behaviour. Thrombus formation in vivo and bleeding time. Thromb Haemost 23: 425-435

VISIOLI F (2000) Antioxidants in Mediterranean diets. In Mediterranean Diets, ed. AP Simopoulos and F Visioli, pp. 43-55. Basel, Karger

VOGNILD E, ELVEVOLL EO, BROX J, OLSEN RL, BARSTAD H, AURSAND M, OSTERUD B (1998) Effects of dietary marine oils and olive oil on fatty acid composition, platelet membrane fluidity, platelet responses, and serum lipids in healthy humans. Lipids 33: 427-436

WANNAMETHEE SG, SHAPER AG (1999) Type of alcoholic drink and risk of major coronary heart disease events and all-cause mortality. Am J Public Health 89: 685-690

WESTSTRATE JA, VAN HET HOF KH, VAN DEN BERG H, VELTHUIS-TE-WIERIK EJ, DE GRAAF C, ZIMMERMANNS NJ, WESTERTERP KR, WESTERTERP-PLANTENGA MS, VERBOEKETVAN DE VENNE WP (1998) A comparison of the effect of free access to reduced fat products or their full fat equivalents on food intake, body weight, blood lipids and fat-soluble antioxidants levels and haemostasis variables. Eur J Clin Nutr 52: 389-395

WOLLIN SD, JONES PJH (2001) Alcohol, red wine and cardiovascular disease. J Nutr 131: 1401-1404 